\title{
BORGES ENTRE AVERROES Y ALGACEL
}

\author{
Luce López-Baralt*
}

\author{
A la memoria de Mikel de Epalza, \\ amigo leal, amigo solidario, \\ amigo admirado, \\ amigo siempre echado en falta
}

El relato «La busca de Averroes», delicado como la maquinaria de un reloj, no es ajeno a la extraordinaria complejidad que ha hecho célebre a Jorge Luis Borges. Como tantas otras piezas del maestro argentino, "la busca" que anuncia el título se torna binaria, ya que Averroes intenta en vano aprehender los conceptos griegos de tragedia y comedia de la Retórica de Aristóteles para verterlos al árabe; mientras que Borges, quien, como autor ficcionalizado del relato, asoma su rostro en los párrafos finales, intenta a su vez apropiarse del entorno cultural islámico del cadí de Córdoba del siglo XII con las herramientas insuficientes de unos modestos "adarmes ${ }^{1}$ de Renan, de Lane y de Asín Palacios" (OC I: 588). El célebre filósofo Ibn Rušd es incapaz de comprender el concepto aristotélico del drama porque sencillamente su cultura árabe carece de la noción del teatro. Lo mismo le acontece a Borges, que busca en vano a Averroes, ya que él, a su vez, no dispone de los elementos suficientes para comprender a fondo la cultura islámica y la lengua árabe del erudito filósofo cordobés.

Advirtamos de entrada que, en un relato que gira en torno a una traducción malograda, Borges evita aludir en el título a la noción misma de la traslación lingüística: nos habla, en cambio, de una "busca". El epígrafe del relato, además, no lee "En busca de Averroes", sino "La busca de Averroes", con lo que el

\footnotetext{
* Universidad de Puerto Rico.
}

1. Borges no elige la palabra antigua de "adarme" en vano. Para significar una "cantidad insignificante", una "miaja", se sirve de un arabismo, muy a tono con el tema que nos ocupa. "Adarme", del hispanoárabe darham (dirham en árabe, derivado del griego drakhmé) apunta al escaso valor adquisitivo de la moneda musulmana, cuyo peso equivalía "a menos de dos gramos". De ahí la poca sustancia asociada usualmente al "adarme" (Cf. Moliner, 1994: II, 52). De otra parte, la moneda, con su disco circular evocador del infinito, constituye un símbolo literario de gran importancia en toda la obra de Borges: el "Zahir" (1949) y La moneda de hierro (1976) son tan sólo dos ejemplos de su proclividad al símil. 
sujeto que lleva a cabo la búsqueda queda ambiguado ab initio. La gramática equívoca sugiere simultáneamente que la acción de la búsqueda la lleva a cabo Averroes, pero también que alguien está "buscando" a Averroes. Averroes, ya lo sabemos, "busca" al inaccesible Aristóteles -él lo llamaba Aristu-pero Borges a su vez busca al célebre cadí de Córdoba con unos instrumentos insuficientes para poder lograrlo de manera exitosa. Los sujetos que "buscan" traducir una cultura ajena y remota en el tiempo se geminan y en última instancia resultan indiferenciados. Otro tanto ocurre con su inútil, esforzada búsqueda cultural. Borges lo sugiere al final de su relato en una escena de sobretonos "mágicos": cuando el filósofo cordobés se mira en el espejo de metal intentando hacer un cotejo ontológico de su persona, de súbito tanto él como su esplendoroso entorno andalusí quedan borrados, para dar paso a la presencia inesperada del autor del relato. Éste toma la palabra y nos deja saber que ha vuelto a repetir una búsqueda cultural tan infructuosa como la de Ibn Rušd. La frustrada "busca" de una cultura inaprehensible resulta pues cíclica y conlleva idéntica frustración tanto para el protagonista Averroes como para el autor ficcionalizado "Borges".

Pero un relato en el que el mismísimo Borges prodigue sus claves es sospechoso. Como siempre, el maestro exige mucho más de su lector, y en este relato lo convida a descubrir que, bajo los intentos fallidos de los dos trujamanes -Averroes y Borges- subyace otra busca aún más vertiginosa y más frustrada, que se perfila como del todo imposible. Los avatares del relato apuntan silenciosamente, como veremos, a esta esforzada "traducción" gigantesca, que de puro osada linda con lo sacrílego.

Cumple que revisemos la apretada trama del cuento, que transcurre en la época almohade, asociada, como se sabe, con el fundamentalismo islámico. El filósofo Ibn Rušd, "cumbre y coda de la fálsafa" o filosofía musulmana, como lo llama Miguel CRUZ HERNÁNDEZ (1996: vol. 2, 517), se encuentra comentando a los clásicos griegos. Ibn Rušd defendió, muy en la línea aristotélica, que el conocimiento intelectual era el único fin de la vida humana y constituía su felicidad suprema. Fue tal su pasión por Aristóteles que se le conoció como el máximo commentator del filósofo. Además, desde su óptica de estricto racionalista, Averroes criticó duramente la cosmovisión teológica de Avicena, de raíz neoplatónica.

El relato borgeano abre con la invocación del lento paso del nombre del cadîn cordobés Abū-l-Walīd b. Rušd a su forma hispanizada de "Averroes": "Abulgualid Muhámamd Ibn-Ahmad ibn Muhámmad ibn Rushd (un siglo tardaría ese largo nombre en llegar a Averroes, pasando por Benraist y por Avenyz, y aun por Aben-Rassad y Filius Rosadis)" (OC I: 582). (Tomemos nota del último apelativo -Filius Rosadis- porque habremos de volver a él.) Borges, como siempre, translitera el árabe sin pruritos científicos, y en su cadena onomástica

2. Borges no alude a ello, pero Averroes también fue un médico muy famoso, autor de numerosas obras como la Paráfrasis de los elementos de Galeno. 
sigue de cerca al orientalista francés Ernest Renan (1823-1892) ${ }^{3}$, quien ofrece dieciséis diferentes transliteraciones del patronímico: Ibin Rosdin, Filius Rosedis, Ibn Rusid, Ben Raxid, Ibn Ruschad, Ben Resched, Aban Rassad, Aben Rois, Aben Rasd, Aben Rust, Averrosd, Averryz, Adveroys, Benroist, Averroyth, Avenroysta (FISHBURN y HuGUES, 1990: 202-203). Arabistas más modernos solventes en la materia ofrecen nuevos apelativos intermedios: "El nombre Averroes procede de la pronunciación del árabe coloquial andalusí o hispanoárabe del modo siguiente: Abán Rušd -Abén Rošd-Abenrošd-Abenrroch" [...] Habida cuenta del silencio sobre su alcurnia y su elogio de todo lo andalusí original, es posible que el término Rušd pueda ser una arabización de un nombre hispano" (CRUZ HERnÁNDEZ, 1986: vol. I, 503-505). Dicho nombre pudo haber sido "Ruiz" o "Roiz". Sea como fuere, lo cierto es que, para nuestros propósitos, Borges documenta desde el inicio mismo de su relato el paso de un nombre árabe hasta su culminación en un nombre hispanizado: de Ibn Rušd llegamos a Averroes.

Estamos ante la versión microcósmica de una de las propuestas principales del cuento: la paulatina conversión de una identidad en otra, el cambio cíclico de una realidad en otra. El primer párrafo de la historia ilustra pues, en apretada metáfora, el camino que se traza de la busca del árabe Averroes hasta la busca del hispanohablante Borges, que es imagen especular de la primera busca. El camino aquí es cíclico, e implica un regressus ad infinitum, no desemejante a los que tantas veces ha modulado el maestro argentino, obsesionado con la circularidad espejeante de libros como el Quijote, el Hamlet y, sobre todo, las Mil y una noches.

Como este ritmo cíclico es medular a la estructura del relato que nos ocupa, cumple recordar que para Borges las Mil y una noches son infinitamente cíclicas cuando tomamos en cuenta la noche "mágica" 602, que exige el regresus ad infinitum a la noche en la que Scheherezade interrumpe sus narraciones para contarle al rey por qué le ha estado narrando sus cuentos para salvar su vida. Le explica, en otras palabras, su propia historia como raconteur. Al hacerlo, Scheherezade tiene por necesidad que volverle a contar al rey Shahryar los relatos que le había ido narrando a lo largo de todas esas noches, a partir del primer relato, hasta que vuelve a llegar a esa noche delirante en la que interrumpe sus narraciones. A partir de aquí es forzoso regresar una vez más a la primera noche en la que comienzan los relatos y así sucesivamente, para volver a comenzar cíclicamente la lectura una vez arribemos de nuevo a la vertiginosa noche $602^{4}$.

Volvamos a «La busca de Averroes». A continuación, el narrador nos da noticia del libro que escribe el estricto cadí racionalista: el Tahāfut-ul-Tahāfut, o la Destrucción de la destrucción, "en el que mantiene, contra el asceta persa Ghaza-

3. El epígrafe que sirve de lema al relato que nos ocupa es precisamente de Renan.

4. Cf. las «Siete noches» $\mathrm{y}$ «Los traductores de Las mil y una noches» de Borges y, para el origen de la noche 602 en las traducciones europeas de las Noches, cf. los atinados ensayos de Evelyn FISHBURN (2004a y 2004b). 
li, autor del Tahafut-ul-falasifa (Destrucción ${ }^{5}$ de los filósofos), que la divinidad sólo conoce las leyes generales del universo, lo concerniente a las especies, no al individuo" (OC I: 582). Tengamos presente que Borges silencia de aquí en adelante la mención del persa Algacel o Al-Gazzālī, que más que asceta -como dice para despistarnos- era un místico que fulminó al kalām o teología especulativa y la fálsafa de los filósofos, incapaces de aprehender la esencia divina con sus métodos de análisis estrictamente racionales. Al-Gazzālī (1058-1111) llevó a cabo su crítica demoledora antirracionalista precisamente en su Tahāfut al-falāsifa, obra que vio ya su primera traducción latina en la Edad Media. No hay que olvidar que si bien Borges admite tener recibido a Averroes a través de Renan, Lane y Asín, también debió trabar un conocimiento muy preciso de Algazel en los cuatro volúmenes del exhaustivo estudio que le dedica el arabista español: La espiritualidad de Algazel y su sentido cristiano (1934-1943). Como se sabe, para el maestro argentino los estudios de Asín Palacios constituían libros de cabecera.

Algacel, perplejo ante las contradicciones ideológicas de las sectas religiosas y de las escuelas filosóficas, tuvo una larga crisis espiritual que lo llevó a estudiar las obras de místicos sufíes de la talla de Abū Țālib al-Makkī, Ŷunayd y Abū Yazīd Basțāmī (CRUZ HernáNDEZ, 1996: vol. I, 275). El persa tuvo a su vez numerosos éxtasis, que explicita en libros apasionados como el Miškāt al-anwār o Nicho de las luces. Libros místicos como éste, que Borges cuida de no mencionar, nos hubieran ofrecido pistas útiles para decodificar más rápidamente el relato, pero, a la luz de las claves adicionales internas que veremos enseguida, no nos será difícil entender que el narrador está haciendo referencia a la teología mística del contemplativo persa, al que tan tenazmente se opuso el racionalista Averroes. Estas claves, evidentes para cualquier islamólogo, las insinúa Borges de la misma manera solapada con la que silencia el hecho de que bajo el Dios manifiesto del zahir subyace el Dios innombrable y oculto del batin: el inesperado reverso de la simbólica moneda argentina ${ }^{6}$.

Algacel fue plenamente consciente de la limitación última de la razón humana para abordar el conocimiento trascendente: "la razón pura no puede alcanzar resultados valiosos porque no fue creada por Dios para actuar por sí sola" (CRUZ HeRnÁNDEZ, 1996: vol. I, 281). De ahí que opte por defender la iluminación del corazón -el órgano simbólico de la percepción mística- que considera la vía auténtica del más alto conocimiento. Esta "ciencia directa de Dios" (CRUZ HERNÁNDEZ, 1996: vol. I, 283) algaceliana es una serena luz interior que nada tiene que ver con las embriagueces místicas exageradas del sufismo popular ni con la gimnasia ascética hueca. Dicho método cognositivo, que debe prescindir de todo afán constructivo apriorístico, permite la aprehensión sin intermediarios del conocimiento último y lleva, entiende el filósofo, a la vivificación de las ciencias

5. A veces la voz ha sido traducida como "la incoherencia" [de los filósofos"]. Cf. FISHBURN y HUGUES, 2004.

6. Para la decodificación de las claves islámicas del relato del "Zahir", cf. LóPEZ-BARALT, 1996 y 1999. 
de la fe, que explora en uno de sus tratados más famosos, que lleva precisamente ese título: Ihy $\bar{a}^{\prime}$ 'ulūm al-dīn. La religión del Islam se revivificaría cuando tomase en cuenta la experiencia religiosa directa, pues la lógica racional tan sólo lleva, insiste Algacel, a resultados contradictorios. Importa aclarar, a todo esto, que el filósofo contemplativo tampoco desdeña la razón humana -tan sólo supedita sus posibilidades cognoscitivas a la vivencia fruitiva mística- ${ }^{7}$, que implica un conocimiento directo y experiencial de las verdades últimas.

Cumple ahora que volvamos a Averroes, el filósofo racionalista antialgaceliano que protagoniza nuestro relato. Ya sabemos que el texto nos ha planteado dos metafísicas encontradas: el racionalismo aristotélico y el misticismo, representados respectivamente por Averroes y por Algacel en el Islam medieval. Borges apunta de pasada al hecho adicional de que en el undécimo capítulo de su Tahafut-ul-Tahafut, cuyo título completo es «Tahāfut al-Tahāfut al-falāsifa li-l-l-Gazzālī», «Destrucción de la destrucción de los filósofos de Algacel» (CRUZ HERNÁNDEZ, 1996: vol. I, 273 y ss.), Averroes mantiene que Dios sólo conoce las leyes generales del Universo, es decir, lo concerniente a las especies, no al individuo. Esto va, una vez más, en contra los postulados de Algacel, que teoriza en el sentido de que Dios crea el mundo deliberadamente desde el principio, y que éste no nace como una simple emanación del Primer Ser (FISHBURN y HUGUES, 1990: 233). En efecto, el Averroes histórico se apoya en el conocimiento de los universales, y propone que las cosas concretas "son generables y corruptibles" (HERNÁNDEZ CRUZ, 1996: vol. I, 525). Algacel, por su parte, ya lo sabemos, defiende la experiencia directa del Dios vivo que no depende de emanaciones ni de búsquedas racionales inútiles. Ya veremos que estos motivos temáticos se habrán de volver a modular, con increíble sutileza, a lo largo del relato.

A continuación vemos cómo el cadí escribe sobre sus disputas filosóficas, eslabonando sus ideas con sinuosas grafías árabes, que corren de izquierda a derecha. Redacta en medio de un espacio seductor de frondas, rumores de fuentes y canturreos de palomas: su amada Al-Andalus. Borges dice verdad: el Averroes histórico no escatimó elogio alguno a su tierra y a sus conciudadanos. Afirma que por la excelente situación geográfica de Al-Andalus en el "clima" o kalām quinto, sus habitantes, de tez clara y cabellos sedosos, eran los más hermosos de la tierra y su región la más privilegiada. Precisamente por eso se habían "multiplicado las ciencias" entre ellos (CRUZ HERnÁNDEZ, 1996: vol. II, 508-509). Averroes, que procede de la estirpe de los árabes del desierto, agradece escuchar el rumor del agua de los lujuriosos jardines de Córdoba, rival de Bagdad y del Cairo. Una vez más, Borges nos asoma a la nostalgia de lo perdido o inalcanzable, de lo que una vez fue y que genera con el paso del tiempo nue-

7. Algacel no es pues extremo en su posición filosófico-mística, y cree en lo que se ha denominado como "el justo medio del conocimiento". El esfuerzo racional se convierte en un instrumento cognoscitivo viable tan sólo cuando está iluminado por la fe y la experiencia directa de la Trascendencia. 
vas realidades. La sangre de Averroes, sensible a las fuentes sonoras, evoca el desierto sediento de sus antepasados, los Banñ Rušd ${ }^{8}$ : de las candentes, indomables arenas árabes hemos llegado a la cultísima urbe de Al-Andalus, refrescada por fuentes ubicuas. Córdoba, por otra parte, rivaliza con las antiguas metrópolis musulmanas: el poder y la civilización de antaño han dado paso a una nueva civilización de cuño magrebí u occidental. Borges parecería seguir ilustrando, con ejemplos renovados, la imagen de la lenta transformación de una cosa en otra, de una persona en otra: es la modulación continua de un cambio que, sin embargo, reitera y evoca la realidad anterior. Como recordaremos, de Ibn Rušd habíamos llegado al nombre de Averroes, y de la busca de Averroes habremos de dar en la busca de Borges. El arabesco literario gira pues incesantemente, desplegando frente al lector nuevas modalidades de una simbólica realidad primera, y todo el proceso evoca la noción de los universales y los particulares, cuya disputa filosófica siguió tan de cerca el cadí cordobés.

Siguiendo el hilo de nuestro relato, he aquí que Averroes, inmerso siempre en su hermoso espacio andalusí, echa de lado el Tahāfut, para echar mano de la Poética de Aristóteles ${ }^{9}$, de cuya sabiduría griega lo separan catorce largos siglos. Borges sopesa la extrema dificultad de la tarea que se ha impuesto el filósofo, que intenta -ya lo sabemos- asediar a Aristu a través de traducciones intermedias, pues no domina ni el siríaco ni el griego. El prurito de Averroes por trasladar fielmente la filosofía aristotélica no es invento de Borges. Un discípulo de Averroes, Abū Bakr Bundūd b. Yahyyà al-Qurțūbī, nos cuenta que había escuchado de labios del propio Ibn Rušd cómo fue que éste se inició en su ardua empresa de trujamán cultural. Un día el sultán de Córdoba, quejoso de la "oscuridad del estilo de Aristóteles y de la dificultad de comprender sus doctrinas" (CRUZ HeRNÁNDEZ, 1996: vol. II, 507), afirmó que tan sólo le sería lícito abordar el estudio de la obra aristotélica a aquél que pudiese comentar y exponer su sentido, "tras haberlo comprendido perfectamente" (ibid.). Muchos concurren entonces en que el único candidato a hacerlo era el joven Averroes. Esta anécdota, que le refiere el cadí cordobés a su alumno al-Qurțūbī, da cuenta pues de los inicios de su consagración a la obra de Aristóteles, de quien será -ya lo sabemos- el máximo comentador musulmán.

Pero el glosador supremo de Aristu se encuentra ante un enigma, ahora no ya de índole filosófica sino literaria: ¿Cómo traducir al árabe las palabras tragedia y comedia, cuyo sentido lo eluden por completo? Al plantear la indefensión cultural de Averroes frente a la cultura griega, Borges se hace eco del estudio de Renan, Averroès et l'averroïsme, publicado en 1852. Cuando Averroes parafrasea la Poética de Aristóteles, apunta el estudioso, lo hace con un conocimiento pro-

8. Sobre la estirpe de Averroes, cf. CRUZ HernánDEZ, 1996: vol. II, 504 y ss.

9. En efecto, en el Libro 2 de la Poética Aristóteles habla de la comedia, que considera representa a los hombres como peores de lo que realmente son; y de la tragedia, que, en cambio, los enaltece y los retrata como mejores de lo que son (cf. FISHBURN y PSICHE, 2004: 192). 
fundo de la literatura árabe, pero con una crasa ignorancia de las letras griegas, que aún no se habían traducido a la lengua coránica. Señala Renan que incluso los comentarios y las versiones latinas medievales de las obras filosóficas de Aristóteles estaban llenas de barbarismos por haber sido refundidas del hebreo a partir de un comentario de una traducción árabe que a su vez se hizo de una traducción al siríaco del original griego (FISHBURN y HUGUES, 1990: 202).

Averroes, que se sabe alejado por el tiempo y los idiomas intermedios de su admirado Aristu, consulta vanamente en su predicamento grandes autoridades como Hunáin ibn Ishaq (Hunayn ibn Ishạaq) y aun de Abensida o 'Alī ibn Aḥmad ibn Sīda (m. 1066). Este último fue un filólogo hispanomusulmán que guarda una curiosa simetría con Borges, ya que tanto él como su padre habían sido ciegos. Pero cuando el cadí va a compulsar las numerosas copias caligráficas persas que posee del Mohkam o Kitab al-Muhkam ${ }^{10}$ de Ibn Sīda (el énfasis en la caligrafía oriental, como habremos de ver, será una pista oculta del relato) ve jugar a unos muchachos. Uno, de pie sobre los hombros de otro que actuaba como alminar, hacía de almuédano y salmodiaba la profesión de la fe -"no hay dios sino Dios" o lā ilāha illā Allāh-mientras que un tercero, postrado sobre el polvo, fingía ser la congregación de los fieles. El filósofo cordobés, sin embargo, no se apercibe de que tiene delante de sí la clave de los enigmáticos términos aristotélicos que tan afanosamente busca: los niños ejecutan su modesta función teatral o "comedia" infantil, que podría terminar, todo sea dicho, también en "tragedia", ya que todos los infantes querían actuar como almuédano y se seguro terminarían peleados por ello. A la vista pues del cadí estaba, podríamos decir que en su estado "individual", "concreto", "corruptible" y "físico", aquello que buscaba abstractamente en sus tratados librescos, que evocan, una vez más, los elusivos "universales". Dios, que creó tan sólo los universales, según expone Averroes en sus Tahäfut, no percibe lo particular: ipsum non apprehendere particularia. Otro tanto el "ciego" Ibn Rušd, ocupado tan sólo de los libros escritos y no de las particularidades de la vida real. No es tan sólo pues el hiato cultural lo que aleja a Averroes de los incomprensibles términos griegos: parecería que no puede separarse de los libros para intentar comprender el mundo.

El filósofo abre ahora otro manuscrito, esta vez del erudito Jalil o Al-Jalīl (n. c. 720), putativo fundador de la filología árabe y autor del primer diccionario en dicha lengua, el qitah [sic por kitab] ul ain o Kitāb ul-'ayn. Averroes se regocija con la hermosa copia el volumen, importado de Tánger, y el nombre del puerto marroquí le hace evocar al viajero Abulcásim Al-Asharí11, con quien

10. El libro del filólogo consiste en un diccionario ideológico de la lengua árabe, y podría traducirse como Diccionario de términos especializados (Cf. CABANELAS, 1986).

11. Evelyn Fishburn (FISHBURn y Hugues, 1990: 4) propone que se podría tratar de Abu-Hussein Ibn Djohein, quien, según Renan, le reprocharía a Averroes el haber perdido su fe. Pero es que hay muchos "Abulcásim"o Abū l-Qāsīm en la cultura islámica antigua, desde un rey taifa de Sevilla del siglo XI, pasando por el célebre cirujano de Córdoba, a quien los occidentales llamaban 
habría de cenar esa noche en casa del alcoranista Farach. Borges debe estar haciendo aquí una alusión críptica a Abū al-Farāŷ Ibn al-Ŷawsī (s. XIII), gran experto en ciencias coránicas y en tradiciones proféticas adscrito a la escuela hanbalí, que fue también un orador, historiador y teólogo sumamente prolífico ${ }^{12}$.

A continuación nos es dado participar, de la mano de Averroes, en un auténtico maŷlis ${ }^{13}$, aquellos doctísimos saraos de la perdida Al-Andalus donde los eruditos asistentes, llamados Zurafä' o raffinés desde tiempos de Bagdad, se entretenían en enaltecidas disputas filosóficas y literarias. Una vez hechas las debidas loas a los gobernantes almohades (recordemos lo proclives que fueron estos gobernantes al fundamentalismo) los doctos festejantes pasan al jardín, donde se disponen a hablar de las rosas. Advierto enseguida que un musulmán culto no habla nunca de la rosa de manera casual, y el dato no le fue ajeno a Borges, autor de poemas de aliento sufí como el estremecido «Unending Rose». Pues bien, los amigos andalusíes abandonan los panegíricos a sus rígidos gobernantes "racionalistas" y celebran con entusiasmo las rosas de sus cármenes, aquellas que inevitablemente asociarían a la Rosa infinita con la que los místicos simbolizaban a Dios. En eso Farach -o al-Farāŷ, el teólogo alcoranista apegado a la letra del libro revelado- evoca una curiosa variedad de la "rosa perpetua", que Ibn Qutaiba había descrito una vez. Abū Muhammad 'Adbullāh bnu Muslim Ibn Quțayba (828-889) fue un erudito profesor de Bagdad experto en retórica coránica y poesía ${ }^{14}$. Esta rosa que describe Ibn Qutaiba se da en los jardines del Indostán, y sus pétalos, de un "rojo encarnado" -es decir, de un encendido color rojo- presentan caracteres que dicen "No hay otro dios que el Dios, Muhámmad es el Apóstol de Dios": la profesión de fe que cantaban, por cierto, los niños cuando jugaban al almuédano. Farach agrega que el viajero Abulcásim debió haber conocido este tipo de rosa en alguno de sus viajes. "Abulcásim lo miró con alarma", escribe Borges enigmáticamente. Si Abulcásim decía que sí, sería considerado como un impostor; si lo negaba,

\footnotetext{
"Abulcasis", hasta el famoso historiador de la corte mongol del siglo XIII que también fue conocido por sus obras acerca de los secretos de la cerámica. Pienso, sin embargo, que el título que describe a Abulcásim -“Al-Asharí"- es importante en el contexto de nuestro relato, ya que parecería apuntar a la escuela teológica de la Aša'riyya, fundada por Abū l-Hasan al-Aš́arī (s. X), que cambió el curso de la teología islámica y la separó para siempre de la teologia cristiana. Estos teólogos "asharís" eran racionalistas pero también tradicionalistas, y uno de ellos se llamó precisamente Abū l-Qāsīm al-Ansarī (s. XII) que también se pudo haber apodado "Al-Asharí" por su pertenencia a esta escuela, dentro de cuyo seno escribó obras teológicas importantes. Borges concibe a su personaje como un viajero, pero acaso el dato sea puramente ficcional.
}

12. Existió otro célebre al-Farāŷ, llamado esta vez Abū al-Farāŷ al-Ișfahānī, pero se trata de un maestro persa del siglo IX que se distinguió como compilador y coleccionista de la antigua poesía árabe. Sin embargo, ya que Borges habla concretamente de un alcoranista, pienso que se debe tratar de Abū al-Farāŷy Ibn al-Ŷawsī.

13. Cf. Cynthia Robinson, 2002.

14. Defendió, por más, la tradición musulmana contra los escépticos, adeptos a las traducciones árabes de la filosofía griega (HUART, 1947: 154). 
quedaría como un infiel. La encerrona que le tiende el alcoranista es realmente muy grave: parecía demasiado milagroso aquello de unos pétalos rojos inscritos con la profesión de la fe, pero era difícil, de otra parte, que un musulmán auténtico negara esta proclamación piadosa.

Pero hay otra razón ontológica harto más profunda que hace del todo imposible la existencia de esta rosa "letrada". Como adelanté, todo musulmán culto sabe que en el trobar clus de la poesía mística sufí la Rosa "perpetua" representa al Dios vivo, al Dios que el visionario aprehende de manera directa y sin intermediarios dogmáticos ni racionales. He aquí que hemos dado (una vez más, de manera velada) con el Dios experiencial del místico Algacel. Esa flor simbólica fue precisamente la "Rosa infinita" del poema borgeano «The Unending Rose», hecha de "ríos, palacios y ángeles" que 'Aț̣ār de Nishapur, claro alter-ego de Borges, quiere volver a ver después de morir.

A la luz de todo esto, la flor del Indostán que describe Farach implica un grave problema teológico-místico: el letrado alcoranista nos ha hablado de una rosa contradictoria, imposible, incluso blasfema, pues sobre sus pétalos infinitos, más allá de toda imagen y sujeción corpórea, ha osado posarse el lenguaje. De ahí su color "encarnado", que alude no sólo al rojo vivo propio de la rosa epifánica, sino a su anómala condición "encarnada" o corpórea, incompatible del todo con la flor sobrenatural de los místicos sufíes. Precisamente de aquellos místicos -importa recordarlo una vez más- con los que se formó Algacel, autor de libros visionarios como el Miškāt al-anwwār. Borges pasa ladinamente en silencio los nombres y las obras de estos sufíes -recordemos a 'Attar de Nishapur, protagonista del "Unending Rose" - que él conocía tan de cerca.

Con todo, es ahora cuando el lector avisado va entendiendo mejor cuán importante era la abreviada alusión que el narrador hizo de Algacel justo al principio del relato, recordando su pugna ideológica con el racionalista Averroes. Estamos ante dos asedios ontológicos encontrados: en un caso se trata de la busca de una cultura ajena; en el otro, de la busca de la Trascendencia. Averroes intenta llevar a cabo ambas buscas a través de la razón humana, y si bien la primera es harto difícil, la segunda ya es del todo imposible.

Por más sagradas y más teológicas que pudieran ser las palabras inscritas sobre la rosa perpetua -se trata nada menos que la profesión teológica de la felas grafías negras, aquellas que con tanto apremio trazaba Ibn Rushd al escribir sus tratados, desacralizan sus pétalos inmarcesibles. La flor sobretatural, ya lo sabemos, representa la esencia infinita de Dios. Y Dios, como postuló Algacel y como sabe todo místico, trasciende el lenguaje, estrictamente racional y temporal. "Detrás del nombre está lo que no se nombra" ("El compás", El otro, el mismo, OC II: 253), proclama Borges a su vez, y lo hace con pleno conocimiento de causa, pues la insuficiencia del lenguaje ante el Misterio último es uno de los leit motivs fundamentales de su obra. Así lo atestiguan textos como «El Aleph», «El Zahir», «La escritura del dios», «Mateo XXV, 30» y «The Unending Rose», entre tantos otros. Parecería entonces que los trazos de la grafía 
árabe maltratan -torturan- con su atrevida torpeza corpórea la lozanía ultramundana de los pétalos de la "rosa perpetua". Dije los "torturan" con toda intención, porque habremos de volver a encontrarnos con esa cruel desacralización de la Trascendencia a manos del lenguaje.

Como al "alarmado" Abulcásim, ya lo sabemos, no le es dado refutar la flor "teológica" propuesta por el alcoranista, evade el problema y musita que en el Señor están las llaves de las cosas ocultas. Los designios divinos son inescrutables, piensa, haciéndose eco de la socorrida noción islámica del wa Allāhu 'alamu: "sólo Dios sabe". Por cierto que Borges usurpa esta frase piadosa a la cual se suele acoger el creyente musulmán ante ciertos enigmas irresolubles y la modula una y otra vez a lo largo de su obra.

Acto seguido Abdalmálik, otro de los festejantes, recuerda otra maravilla: algún viajero aseguró haber visto árboles cuyo fruto eran verdes pájaros. Aunque no lo dice, alude al libro de las Noches, pródigo en fantasía, pues Scheherezade se refiere a tal árbol en el relato de Buluqiya (LÓPEZ-BARALT, 2004). Y esto lleva a Farach a exponer largamente otra mirabilia aún mayor, que aborda, como era de esperar, desde "la doctrina ortodoxa" coránica a la que es tan adepto. Se trata ahora de la teoría islámica de "la Madre del Libro" o umm al$k i t \bar{a} b$, que postula la existencia de un arquetipo increado del Corán en el cielo, del cual el Corán que reveló el Arcángel Gabriel a Mahoma en el siglo séptimo es una simple epifanía:

"El Qurán (dijo) es uno de los atributos de Dios, como su piedad; se copia en un libro, se pronuncia con la lengua, se recuerda en el corazón, y el idioma y los signos y la escritura son obra de los hombres, pero el Qurán es irrevocable y eterno" (OC I, 584).

Averrroes reflexiona irónicamente que este Corán increado "es algo asî como su modelo platónico" (OC I, 584), pero se abstiene de más comentario pues sabe que la teología era un tema inaccesible a Abulcásim. No nos extrañe la extrapolación del cadí, tan apegado a la doctrina de los universales. El Corán increado sería un "universal" frente a la realidad creada de un "particular" corruptible: el Corán del siglo VII dictado en lengua árabe a Mahoma. Dado el contexto del relato que hemos visto hasta ahora, sin embargo, es obvio que volvemos a hollar terreno místico. El Corán encarnado -recordemos el incómodo adjetivo que dio el narrador al color de la rosa infinita- jamás puede equipararse al Corán eterno, igualmente infinito y por ello mismo a puerto seguro del lenguaje humano. Una vez más, la filosofía de Averroes se enfrenta silenciosamente con la mística de Algacel. El primero, como Farach, se conformaría con estudiar la palabra dictada en árabe al Profeta, mientras que el segundo optaría por la experiencia fruitiva del Corán ultramundano, eterno y uno con el mismo Dios y más allá, por lo tanto, de toda posible especulación teológica.

Pero he aquí que los raffinés siguen prodigando el recuento de las "maravillas" del mundo creado. Averroes reflexiona que estos portentos son imposibles de articular con el lenguaje, ya que son, en última instancia, incomu- 
nicables: "la luna de Bengala no es igual a la luna del Yemen, pero se deja describir con las mismas voces" (OC I: 584-585). Habremos de volver a ello, pero por el momento cabe decir que esta crítica del lenguaje, tan cara al pensamiento de Borges, se potencia precisamente en los escritos de Algacel. El místico persa sabe bien que Dios es imposible de inscribir en la palabra humana, que suele referirse a El con imágenes desvalidas e insuficientes.

Los festejantes dirimen ahora una nueva maravilla, la de Sin Kalán en Cantón, "donde el río del agua de la vida se derrama en el mar". Es Abulcásim quien refiere la anécdota, y le responde el alcoranista, preguntándole si la ciudad quedaba a muchas leguas de la muralla que Iskandar Zul Carnain había levantado para detener a Gog y Magog. La alusión tiene sobretonos fantásticos pero, como era de esperar por estar en labios de Farach, es estrictamente coránica, ya que en la azora 18:92-8 se alude a este Dū 1-Qarnayn o Alejandro Bicorne, a quien conocemos en Occidente como Alejandro Magno. El Alejandro Bicorne coránico construye una fortaleza contra Gog y Magog, para que no asolaran la tierra de un pueblo desvalido. De acuerdo a una leyenda siríaca, Gog y Magog intentaban escapar cada noche de su prisión escarbando bajo el muro, pero antes del amanecer Dios siempre reparaba la brecha que habían abierto. Salta a la vista que el estricto literalista Farach todo lo interpreta de acuerdo a la palabra revelada del Corán.

Abulcásim apunta que la distancia desértica que separa el prodigio de Sin Kalán de la muralla de Zul Qarnáin se medía en más de ochenta días de camino, y aun así nadie había podido divisar el muro de Alejandro Bicorne. Averroes, a quien siempre lo atemorizó "lo crasamente infinito" (OC I: 585), se estremece al imaginar tal distancia. La alusión al desierto suscita, una vez más, la idea de eternidad ${ }^{15}$, como tantas otras veces ocurre en la obra de Borges, tan adepto a las simbólicas arenas infinitas del libro de su vida, las cíclicas Mil y una noches. El maestro argentino llega incluso a titular uno de sus textos El Libro de arena, por considerarlo "inacabable". Averroes, cuya estirpe árabe es oriunda asimismo de las arenas del desierto, pese a vivir en la civilizada Córdoba, mira humillado su pequeño, simétrico jardín. Este reducido espacio particular representa lo poco que el hombre ha logrado domeñar, pues jamás podrá abarcar el desierto infinito, símbolo de lo universal. Y, sobre todo, símbolo de lo Eterno, que trasciende siempre la razón humana, aquello que para Algacel tan sólo se puede aprehender con el corazón iluminado. Averroes, que se había sentido humillado por su fracaso de trujamán cultural fallido, intuye de súbito su derrota filosófica, y de repente se supo "envejecido, inútil, irreal” (OC I: 585).

El prodigio de Sin Kalán, que evoca, como vemos, problemas metafísicos muy complejos, no pudo ser aprehendido por el entristecido cadí por razones culturales elementales, que constituyen el nivel más accessible del rela-

15. También las arenas, como es obvio, evocan el tiempo, si pensamos en los antiguos relojes de arena. 
to que nos ocupa. Abulcásim describe el exótico portento, que está constituido por una casa de madera pintada con muchas personas, a manera de un solo cuarto, con una fila de alacenas o balcones, unos encima de los otros. En esas cavidades había gente que comía y bebía, mientras que en la terraza, al son del tambor y el laúd, una veintena de personas con máscaras de color carmesí rezaban, cantaban y dialogaban. (Una vez más, topamos con el color rojo, invocado ahora por cierto con la voz qarmasí, de origen árabe.) Cabalgaban, pero no se percibía el caballo; sus espadas eran de caña, no de acero; morían y después estaban de pie. No estaban locos, ya que figuraban una historia, aseguró Abulcásim convertido en apologista de una función que apenas recordaba y que le había disgustado cuando le fue dado presenciarla. Nadie en el refinado sarao comprendió ni quiso comprender: una vez más, Averroes estaba ante la noción misma del drama, que no alcanzaba a entender ni en la Poética ni en la Retórica ${ }^{16}$ de su dilecto Aristu, y mucho menos en el teatro de la lejana China que le relatara Abulcásim. Ya sabemos que el cadí era impenetrable a sucesos culturales que no estuvieran integrados a su propia civilización islámica. Los ejemplos se le prodigan generosamente, pero se mantiene ciego ante ellos.

El alcoranista Farach se muestra convencido de la futilidad del prodigio de Sin Kalán, ya que un solo hablante -halaiquí lo llaman en árabe- era capaz de relatar por sí solo cualquier historia. Indiferentes ante el enigmático prodigio chino, los amigos celebran a continuación la poesía árabe. Abdalmálik moteja de anticuados a los repetitivos poetas de Damasco o Córdoba, aferrados a la inútil reiteración de las antiguas imágenes beduinas. Lleva razón el festejante: esta modulación casi infinita de las imágenes tradicionales ha sido motivo de polémica en la poesía clásica árabe, que muchos al día de hoy consideran agotada por su reiteración excesiva. Para sustentar su punto, Abdalmálik argumenta una resplandeciente imagen de Zuhair, que comparó el destino con un camello ciego ${ }^{17}$. El poeta preislámico Zuhair o Zuhayr b. Abī Sulmà (siglo VI

16. Aristóteles habla del teatro y de la oratoria en el Libro III de su Retórica, en el que explora también, y una vez más, los conceptos de comedia y tragedia (Cf. FISHBURN y PSICHE, 2004: 204).

17. Zuhayr, acaso el mejor de los poetas preislámicos, fue célebre por sus panegíricos, que entreveraba de reflexiones profundamente religiosas, como nos recuerdan Federico CORRIENTE y Juan Pedro Monferrer (2005:124). Murió a los ochenta años, si vamos a dar crédito a sus versos. Se dice que su hijo era también poeta y le leía sus versos a Mahoma. Las casidas de Zuhayr tratan de temas beduinos propios de la vida nómada del desierto y, como era de esperar, abundan en imágenes de la fauna del desierto. Insisto en ello porque me temo que el verso que tanto impresionó a Abdalmálik y, de seguro, a Borges, resulta más hermoso y más dramático en las versiones inglesas que en el árabe original. Borges alude de pasada que "Zuhair comparó el destino con un camello ciego" (OC I: 586). La versión inglesa de Mary Catherine BATESON (1970: 158) incorpora la mención del camello ciego - "I saw destiny (as) the trampling of a night-blind camel"-, mientras que la de CORRIENTE y MONFERRER (2005: 125) es más fiel al original árabe: "Veo que la muerte ciegamente golpea". He cotejado el original árabe, editado en Beirut (Dār Ša'b, 1981: 85) y he podido ver que Zuhayr alude metafóricamente al destino, al porvenir o a la dirección de la voluntad, que golpea o atropella ciegamente al que alcanza. El término árabe que indica lo ciego del golpe alude literalmente a la "ceguera nocturna". La inter- 
A. D.) tuvo tal fama que los poemas de su Al-Mu'allaqat-mohalaca la llama Borges- ganaron el alto honor de ser suspendidos de las paredes de la Caba. Al$M u^{\prime} a l l a q \bar{a} t$ significa precisamente "los suspendidos", frase que hace referencia a los siete poemas de siete poetas galardonados con dicho honor. Aun estando pues ante un poeta supremo, Abdelmalik considera que después de cinco siglos la imagen literaria se había gastado.

Averroes, sin embargo, no está de acuerdo: el asombro que puede producir el relámpago de novedad de una imagen literaria es perecedero, pero un poeta realmente no es un inventor, sino un descubridor. Todos hemos vivido en carne propia, argumenta el docto cadí, la imagen de Zuhair al sentir que el destino es fuerte y torpe, inocente e inhumano. "El tiempo, que despoja los alcázares, enriquece los versos" (OC I: 586-587), asegura el cordobés, y pasa a demostrarlo con unos versos célebres que Abdurrahmán o 'Abd al-Rahmān I, el príncipe omeya que funda el califato de Córdoba, entona desde sus jardines andalusíes recordando su Damasco natal: "Tú también eres, ¡oh palmera! / En este suelo extranjera"18. Asegura Averroes que esos mismos versos lo con-

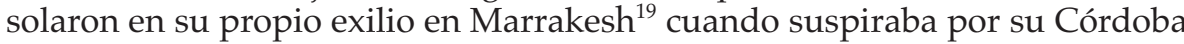
perdida. La poesía se enriquece con el paso del tiempo, pues es posible "confundir nuestros pesares con los de aquel árabe muerto" (OC I: 587), es decir, nos es dado revivir cíclicamente lo experimentado por el antiguo poeta. Claro que los amigos no comprenden a fondo el elogio que hace Averroes a Zuhayr, y se limitan a celebrar que vindicara lo antiguo.

pretación de que lo que produce el golpe brutal del destino sea un camello "ciego" puede justificarse no solo por la abundante mención del camello a lo largo de la casida, sino porque unos escasos versos más adelante el poeta dice que quien "no disimula" o no "aprende a conciliar las cosas" (es decir, quien no es astuto y flexible ante la vida) es "desgarrado por colmillos y hollado por pezuñas". Pienso que esta violencia desatada de un animal salvaje podría extenderse al destino, que se convierte entonces metafóricamente en un "camello".

El pasaje que nos interesa se inicia con la queja del poeta, que ha alcanzado los ochenta años y admite sentirse cansado de la vida, ante cuyo mañana se declara ciego. Esta es mi propia versión española del verso elegido por Borges como inolvidable:

"Vi el destino como el golpe brutal de un camello ciego en la noche -mata al que alcanza, mientras el que escapa, vive hasta la decrepitud".

18. 'Abd al-Rahmmān, exilado en tierras del Al-Andalus y sintiendo la punzante nostalgia de su Damasco natal, compuso el célebre poema que cita Borges, y que ha sido considerado como el poema fundacional de Al-Andalus. Ofrezco la versión completa del poema en español, que he traducido a partir del original árabe y la versión inglesa de D. Fairchild Ruggles (cf. DODDS y MENOCAL, 2008: 62):

Una palmera se yergue en medio de Rusafa

Ha nacido en Occidente, lejos de la tierra de las palmeras

Le dije: ‘¡cómo te pareces a mí, distante y exilada!'

Separada por largo tiempo de la familia y de los amigos,

Has emergido de un suelo que te es extraño

Yo, como tú, también estoy muy lejos de mi hogar'.

19. Se trata de un exilio histórico motivado por distintas razones, tanto políticas como causadas por sus "impías ideas filosóficas", a las que Averroes se consagraba, según sus detractores, en lugar de atender más sus deberes religiosos (CRUZ HERNÁNDEZ, 1996: vol. II, 508). 
Una vez el cultísimo sarao concluye al amanecer, Averroes regresa a su biblioteca y traduce al fin las palabras enigmáticas de Aristu con "firme y cuidadosa caligrafía" (OC I: 587). Advirtamos que el lector se ve precisado a visualizar una vez más los trazos elegantes y curvos de la grafía árabe. Tragedia, escribe el cadí, equivale a "panegíricos" y comedia a las "sátiras y anatemas". Ambas modalidades literarias, comenta Averroes en su tafsir, se hallan en el Corán y aun en las mohalacas del santuario de la Caba. Salta a la vista que Averroes no ha entendido las pistas que las experiencias particulares de la vida le han ofrecido. Encerrado en el orbe estricto de su cultura, se refugia tan sólo en ella y no logra comprender el concepto del teatro, hijo de civilizaciones distintas de la suya.

Averroes tampoco se entera de otro suceso al que el narrador alude de manera fugaz, disimulándolo entre corchetes y pasándolo casi de contrabando: "(En el harén, las esclavas de pelo negro habían torturado a una esclava de pelo rojo, pero él no lo sabría sino a la tarde)" (OC I: 587). La brevísima escena es demasiado incongruente como para ser banal. No añade nada a la trama del relato, por lo que debe estar cuidadosamente codificada, como suele suceder en la cuentística à clef de Borges. En el pequeño drama del harén se encierra, una vez más, la otra busca de Averroes a la que he venido aludiendo, la busca que le habría de resultar todavía más ominosa que sus esfuerzos fracasados de trujamán de culturas. Esta busca que el narrador disimula se relaciona precisamente con el Tahāfut-ul-Tahāfut al-falāsifa li-l-Gazzālī, o Destrucción de la destrucción de los filósofos de Algacel que escribió Averroes para refutar las ideas ontológicas del místico persa y que Borges menciona, como sabemos, al inicio mismo del relato.

Veamos más detenidamente la escena: en el mundo cerrado del harén -harāmm significa en árabe "lo prohibido" - las esclavas de pelo negro torturan a la única esclava que ostenta el pelo rojo. No nos extrañe la rojiza cabellera, que algunas mujeres de la Córdoba omeya, como la poeta Wallāda, poseyeron en la realidad histórica. Pero el dato no tiene aquí interés circunstancial sino simbólico: las cabelleras negras, onduladas y ensortijadas como la sinuosa grafía árabe con la que tantas veces hemos visto escribir a Averroes sus comentarios fallidos, parecerían justamente evocar la escritura. No es la primera vez que Borges metaforiza el negro de la tinta con imágenes alusivas. La combinación del color negro, usualmente junto al amarillo, se suele identificar con la palabra escrita, es decir, con los trazos de la tinta sobre el papel o el pergamino (ECHAVARRÍA, 2006a). Borges se sirve a menudo de este leit motiv: en «La escritura del dios», el jaguar tenía marcas negras sobre su pelaje amarillo; en «Abenjacán e Bojarí, muerto en su laberinto», que trata sobre la traducción del texto de Las mil y una noches, hay un esclavo negro y un león amarillo (LÓPEZ-BARALT, 2011), mientras que en «El jardín de senderos que se bifurcan» (OC I: 479-480), el argentino se refiere a un "amarillo y negro jardín" (ECHAVARRíA, 2006a). Todas estas imágenes evocan los trazos de la escritura, crucial al sentido de cada uno de los relatos en cuestión.

En «La busca de Averroes», sin embargo, no aparece el color amarillo, propio del pergamino, sino el rojo -la tonalidad del cabello de una única mujer del 'arām- que las pelinegras martirizan sin que alcancemos a saber por qué. Para comprender la escena importa recordar las distintas modalidades del rojo 
que Borges ha ido articulando cuidadosamente en su relato. Las máscaras de los actores chinos eran de color carmesí, y la tonalidad cromática se asociaba allí con un hecho literario lejano e incomprensible. En otras palabras, con la cultura ajena que Averroes no ha logrado aprehender. Más extremo aún es el caso de la rosa perpetua a la que había aludido el docto Ibn Qutaiba. Era roja, y ya sabemos que era una flor imposible porque a pesar de ser infinita exhibía en sus pétalos encarnados las sinuosas grafías árabes que dictaban la profesión de la fe islámica. Los grafías teológicas torturaban pues el rojo impoluto de la rosa sagrada, que jamás debió ser mancillada por el lenguaje humano. La estricta unicidad de esta Rosa simbólica del Dios infinito -única como la solitaria pelirroja del harén-, se celebra innumerables veces en el Corán ${ }^{20}$.

Algacel supo bien de la epifanía de la Rosa o "ciencia directa de Dios", cuyo órgano de percepción es, ya lo sabemos, un corazón iluminado sobrenaturalmente (CRUZ HERNÁNDEZ, 1996: I, 282-283). Pero no lo alcanzó a comprender Averroes: "él no lo sabría sino a la tarde" (OC I: 587), apunta el narrador. Esto es, a la tarde de la vida ${ }^{21}$ : después de muerto, cuando se abriera para él un nuevo plano de conciencia, tal como anhelaba 'Attar de Nishapur al final del poema «The Unending Rose».

Averroes no ha entendido pues ninguna de las pistas que le hubieran abierto los ojos, y que el maestro argentino encubre bajo el color rojo: ni la pista de la máscara china carmesí, alusiva a su miopía cultural; ni la pista de la Rosa perpetua encarnada, alusiva a su ceguera metafísica de filósofo racionalista. La extraña disputa en el harén también le pasa desapercibida. Parecería que para Averroes es un asunto acaso demasiado "particular" frente a los temas más "universales" en los que se solía enfrascar. Pero ya sabemos que la misteriosa reyerta femenina del harén representa otras luchas metafísicas más arduas.

Todas estas alusiones cromáticas nos preparan para entender mejor el sentido de uno de los sobrenombres atribuidos al cadí cordobés Ibn Rushd en trance de convertirse en Averroes: Filius Rosadis. Borges destaca el apelativo al dejarlo al final del listado en el que consigna los nombres intermedios del filósofo. Este nombre vendría a significar algo así como el "hijo (Ibn) de lo Rosado", aunque en latín sería más adecuado decir Filius rosae o aun Filius rosacei. Pero lo que importa aquí no son los pruritos etimológicos, sino lo que Borges dice entre líneas: Averroes no alcanza nunca a aprehender el simbólico rojo puro, que lo evade tanto cultural como metafísicamente, y queda pues como un pálido, desvalido "hijo rosáceo" del carmesí y del encarnado.

20. Véanse las azoras II,163; VI, 19; XVI, 22; XXIII, 91-92; XXXVII,1-5; XXXVIII, 65-68 y CXII, 1-4, entre otras. Estamos ante lo que los musulmanes llaman técnicamente el Tawhīd o la Unicidad inviolable de Dios.

21. En los Dichos de luz y de amor, San Juan de la Cruz acuñó la célebre frase "A la tarde, te examinarán en el amor". El poeta místico se refería, claro está, a "la tarde de la vida", es decir, al final de la vida. Borges, como se sabe, leyó cuidadosamente a San Juan de la Cruz, a quien calificó como "the greatest of Spanish poets" (BORGES, 2000: 60). 
Borges se ha servido en otras ocasiones de juegos cromáticos semejantes: el Zahir, nos dice, es "la sombra de la Rosa" -no la Rosa-. Es decir, un mero eco de la inarticulable Rosa perpetua, ya que Zāhir significa en árabe el Dios manifiesto o verbal de los teólogos, frente al bātin (innombrado, como era de esperar, en el relato), que apunta al Dios vivo de la experiencia epifánica directa y que resulta inarticulable al lenguaje humano. La simbólica Rosa sufí no es accesible ni por la razón ni por el lenguaje: ante ella somos pura sombra, hijos pálidos de lo Inmarcesible.

Al final del relato, ya lo sabemos, asoma la cabeza del "autor" ${ }^{22}$, Jorge Luis Borges, que sustituye el rostro borrado del filósofo Averroes, desvanecido en su antiguo espejo de metal. Recibimos en estos momentos la noticia de que ambos, personaje y autor, comparten "el proceso de una derrota" (OC I: 587). En el nivel primario del relato, estamos ante el intento fallido de ambos trujamanes -Averroes y Borges- que se esfuerzan por traducir una cultura ajena sin las herramientas adecuadas. Como advertimos desde el principio, la busca fracasada se torna cíclica: Averroes busca a Aristóteles y Borges busca a Averroes. La primera busca reitera ad infinitum la otra. Además, los lectores del relato habremos de buscar a nuestra vez al elusivo, cultísimo argentino que ha vuelto a soñar la antigua pesquisa frustrada del cadí cordobés. Y habremos de hacerlo, asimismo, como trujamanes falaces, con unos escasos adarmes culturales: a los estudios de Renan, Lane y Asín acaso podríamos añadir muchas más lecturas, pero desde nuestra lejanía especial y temporal de lectores siempre quedaremos con una traslación cultural insatisfactoria. Borges es el fallido Ibn Rušd; nosotros somos el derrotado Borges.

La reactualización cíclica de esta trujamanía fracasada nos lleva a reflexionar sobre la teoría de la literatura y de la traducción en la obra de Borges. Cumple que nos ocupemos en primer lugar del caso de la literatura. De la misma manera que los nostálgicos versos de Abderramán a la palmera africana le sirven a Averroes para confundir sus pesares con los del árabe muerto, así Borges revivifica la frustrada traducción de Averroes, y presagia, como dije, nuestra futura busca como lectores del relato. Atestiguamos con esto que la literatura se enriquece con el paso del tiempo, por el contrario del despojo que hace con los alcázares y las personas, como había observado el personaje Averroes. Esta idea acerca de la literatura se reitera, como ha visto Arturo ECHAVARRía (2006a), a lo largo de la obra de Borges. En «La esfera de Pascal» el argentino lo enuncia con énfasis al referirse a las reescrituras de la noción simbólica de la esfera, con la que tantos han ponderado acerca de la esencia de Dios y del Universo: "Quizá la historia universal es la historia de la diversa entonación de algunas metáfo-

22. El recurso parece cervantino, pues el "autor" Miguel de Cervantes asoma también su cabeza al final del Quijote, surgiendo inesperadamente para reemplazar la voz femenina de la pluma de Cide Hamete, que ha estado hablando suspendida de una espetera de cocina (Cf. LópeZBARALT, 1999 y 2000). 
ras" (OC II: 14). Estamos, puntualiza ECHAVARRÍA (2006a: 69-70), ante una concepción cíclica de la literatura, que implica una memoria compartida. Alexander COLEMAN y Efraín KRISTAL (2002: 10) han observado a su vez que esta proclividad de Borges hacia la despersonalización y la anonimia que conlleva una literatura de carácter cíclico debe mucho al ensayo de T.S. ELIOT «Tradition and the Individual Talent» (1941). Averroes repite los versos de Abderrramán y Borges repite la historia de la busca de Aristóteles por parte de Averroes, mientras que nosotros repetiremos a nuestra vez la busca de Borges en pos de Averroes: ante este circuito inacabable, resultaría baladí pensar que la literatura fuera capaz de una innovación absolutamente "original". Borges no parecería compartir pues la noción estética de Abdelmálik, que pedía la renovación de las antiguas imágenes poéticas beduinas. Para él, como para su hijo de ficción Averroes, tiene más peso literario el reiterar -el redescubrir- las emociones antiguas de poetas perdidos en el tiempo y fundirnos en ellas.

Esta concepción de la litertura conlleva la "reproducción instantánea de un tiempo" (ECHAVARRÍA, 2006a: 70) y aun la anulación de la identidad personal. Borramos nuestra propia identidad de lectores al hacer nuestras las emociones literarias antiguas: Averroes es por unos momentos Abderrahmán; Borges es Averroes por otros instantes, y nosotros los lectores seremos Borges al replantear en nuestra lectura su busca de Averroes. El maestro argentino lo explicita claramente en su «Nueva refutación del tiempo»: “¿Los fervorosos que se entregan a una línea de Shakespeare no son, literalmente, Shakespeare?" (OC II: 141). El carácter cíclico de la literatura conlleva pues un triunfo secreto: la refutación del tiempo. Siquiera, la momentánea anulación del tiempo.

Pero este lenguaje compartido, que reitera cíclicamente las emociones de los escritores del pasado, conlleva un obstáculo insalvable: "la insuficiencia del lenguaje personal" (ECHAVARRÍA, 2006a: 73). Esta memoria compartida, en efecto, entorpece la comunicación eficaz de lo que se ha vivido de manera subjetiva y única. Borges lo enuncia claramente en el relato que nos ocupa, y lo volvemos a citar: "la maravilla es acaso incomunicable: la luna de Bengala no es igual a la luna del Yemen, pero se deja describir con las mismas voces" (OC I: 584-585).

Esto nos lleva a comprender mejor un curioso comentario que hace Borges al dar por terminado su relato de la busca de Averroes. En vez de regocijarse por el consolador triunfo momentáneo que ha logrado sobre la tiranía del tiempo, que parecería "anular" al sumir su identidad con la del buscador Averroes, el autor declara que todo lo que ha narrado es, sin más, "el proceso de una derrota" (OC I: 587). Claro que en un primer plano textual sabemos que Averroes no sabe griego y que Borges no domina el árabe, y que mal podrían abordar las escrituras antiguas que tanto buscan. La frase alusiva a la derrota hace que el texto se muerda la cola y regrese a su principio. Pero Borges mismo enseguida va a hacer meridianamente claro que la derrota de Averroes y la suya propia no eran exclusivamente de índole cultural. Eso sería demasiado sencillo, pues, como dejé dicho, el mismísimo narrador ha explicitado en sus propias palabras este particular fracaso. 
En este preciso punto del relato, y de manera inesperada, el narrador pasa a aludir a derrotas descomunales en el orden metafísico. Para ilustrarlas nos habla del intento de "aquel arzobispo de Canterbury" (OC I: 587) que se propuso demostrar que hay un Dios; de los alquimistas que buscaron la piedra filosofal y de los vanos trisectores del ángulo y rectificadores del círculo. Estamos en terreno teológico-místico, ya que la primera alusión es al célebre argumento de San Anselmo (c. 1033-1109), arzobispo de Canterbury, que intentó probar la existencia de Dios con argumentos escolásticos puramente racionales; la segunda, a la inútil búsqueda de los alquimistas que buscaban en sus primitivos laboratorios lo que debían buscar en su propia experiencia interior y, por último, a la desasosegante imagen de la esfera, con la que Parménides, Pascal, Hermes Trismegisto y tantos otros quisieron conjeturar la geometría imposible del Dios infinito. Estos asedios racionales y lingüísticos, lo sabe bien Borges, siempre quedan derrotados ante la esencia infinita de la Trascendencia.

Pero estos mismos argumentos, tan claramente teñidos de teología, no son fortuitos, ya que nos devuelven de manera obligada al principio mismo del relato. Allí, como recordaremos, Borges plantea el hecho de que Averroes disputa en su Tahāfut-ul-Tahāfut con el Tahāfut-ul-falāsifa de Ghazali. Ya adelanté que en ese libro Algacel argumenta contra el pensamiento racional limitado de los seguidores de la fálsafa o filosofía. Es precisamente en el contexto del pensamiento místico del célebre persa que podemos entender la busca fracasada de los teólogos al cierre del relato. También ahora podemos contextualizar con mejor conocimiento de causa la "rosa perpetua", que no debió nunca estar encarnada en el lenguaje que "torturaba" sus pétalos, de la misma manera que las esclavas de negra cabellera "torturaban" a la única esclava de cabello rojo, azafranado como la simbólica Rosa infinita. También entendemos mejor ahora la modulación por parte de Borges del motivo de la "Madre del libro" o umm al-kitāb: una cosa es el Corán increado, infinito, eterno y uno con Dios, y muy otra su epifanía histórica y "particular" en la Arabia de siglo VII.

Esta preocupación metafísica no es ajena a Borges. El argentino ha reiterado la derrota del lenguaje ante lo inefable trascendente -la última maravilla o undr- en el resto de su obra. Ahí está el Aleph del sótano de la calle Garay, aquel que lo llevó a su máxima "desesperación de escritor" (OC I: 624). Ese Aleph era "falso" porque quedó inscrito en el torbellino de imágenes que urde Borges para acercarnos a la noción de lo infinito. El orbe cristalino contenía las imágenes simultáneamente, pero el narrador las falsea al transcribirlas con su lenguaje sucesivo. El "verdadero" Aleph, en cambio, oculto en el pilar de una mezquita de Cairo, era percibido como un difuso, "atareado rumor" -soplo, logos o pneuma- por lo que nunca fue articulado, es decir, "falseado" por la palabra humana ${ }^{23}$. Otro tanto, ya lo sabemos, ocurre con la cara oculta de la mo-

23. Cf. López-BARAlt, 1999b. 
neda del Zahir, que Borges se cuida de no enunciar nunca. Curiosamente, también pasa en silencio la busca más importante del relato: la del racionalista Averroes y la del místico Algacel. Ambos, cada uno con herramientas distintas, buscaron la Verdad más elusiva de todas: la Trascendencia.

El maestro argentino se sabe a su vez un trujamán fracasado en materia mística, y con ello, irónicamente, demuestra su auténtico expertise en el tema. La traducción de la experiencia epifánica del Dios vivo es literalmente imposible, y Borges nos lo ha dejado dicho en su relato de múltiples maneras. Es por eso que Borges asocia su "derrota" al final del relato no tan solo con traducciones fallidas del griego o del árabe -eso es algo demasiado obvio- sino con el fracaso ontológico de los teólogos racionalistas y de los alquimistas desviados.

Importa insistir en que la palabra "derrota" que sirve de broche de oro al relato no constituye una elección casual. Borges se sirve de ella cuando alude a la trujamanía imposible del místico en uno de sus poemas más conmovedores, «Mateo XXV, 30» (OC II: 252). Allí nos dice que una voz infinita dentro de sí le dijo "estas cosas, no estas palabras, / que son mi pobre traducción temporal de una sola palabra". Mi pobre traducción temporal: estamos ante una traslación inadecuada de la epifanía atemporal recibida, y de ahí "la falsía, la derrota, la humillación" que siente ante su fracasada trujamanía. La busca más crucial de todas tiene como consecuencia la derrota más descomunal de todas. Borges modula esta idea a lo largo de toda su obra.

Salta a la vista que la estructura del relato guarda unas simetrías vertiginosas. Averroes y Borges buscan una cultura inalcanzable, pero también ambos buscan articular la maravilla última -mucho más desasosegante que el teatro griego o chino- con el pensamiento racional, del cual es hijo el lenguaje. Averroes disputa duramente con Algacel porque tiene fe en la razón especulativa; Borges a su vez ha intentado siempre condensar la vivencia infinita en el lenguaje: ya me he referido a los esfuerzos titánicos del "Aleph", del "Zahir" y de «Mateo XXV, 30».

Esa última busca -la más derrotada de todas pues implica articular lo infinito con la palabra humana- se insinúa silenciosa pero sagazmentemente a lo largo del relato. Como una perfecta partitura musical, él mismo abre planteando las dos buscas -la cultural y la metafísica- las enlaza y las va alternando en el cuerpo del texto para terminar por volverlas a unir al cierre de la obra.

Se trata pues de dos buscadores, de dos buscas y, naturalmente, de dos derrotas. Todo resulta perfectamente binario, como es usual en Borges, que nos habla de dos Alephs y de la moneda de dos caras del Zāhir / Bātin. Las dos buscas -la cultural y la metafísica- son, por más, cíclicas. Cada vez que leamos el relato estaremos repitiendo la doble derrota: la improbable traslación de una cultura a otra; la imposible traducción de una vivencia infinita. Con esto la estructura del relato se nos convierte en una caja china o una vertiginosa esfera concéntrica, como las noches cíclicas de Scheherezade, que habrían siempre de regresar a su punto de inicio a partir de la noche 602. 
Pese al vértigo de la doble derrota, nos consuela acercarnos a esta esfera literaria que se repliega incesantemente sobre sí misma, porque al hacerlo parecería que detenemos el tiempo un instante para ser uno con Averroes y Borges y sus buscas compartidas. Ya dije que éste es uno de los milagros secretos del relato: la refutación del tiempo, siquiera -valga la paradoja- momentánea.

Dije al principio del presente ensayo que, pese a que estamos ante una traducción obviamente frustrada, Borges habla de una busca. Aunque parecería que la búsqueda metafísica es más relevante en el relato que la búsqueda cultural, no vale tampoco desdeñar la trujamanía literaria, porque Borges ha teorizado largamente sobre ella. Importa que atendamos, para terminar, la importante función que la teoría borgeana de la traducción tiene en este relato, cimentado, prima facie, en traducciones literarias fracasadas. Desde la óptica de lo que Borges ha dejado dicho sobre la traducción, «La busca de Averroes» se refracta a una nueva luz y nos ofrece claves escondidas adicionales.

Ante la peculiar valoración que Borges otorga a la traducción en otros momentos de su obra, resulta curioso que en este relato sugiera que estamos ante una doble traducción fracasada: Averroes lleva a cabo una traducción frustrada de Aristóteles porque no comprende los términos de la cultura griega que desea verter al árabe, y tampoco Borges mismo logra aprehender la cultura árabe de Averroes con sus escasos adarmes de Renan, Lane y Asín. Pero es que, como observa atinadamente Efraín KRISTAL (2002), al maestro argentino realmente no le ofendía la inexactitud de una traducción, ni consideraba que ésta pudiera constituir una "traición" al original.

Borges desconfía de las traducciones literales por no ser literarias, y admite que prefiere algunas versiones traducidas antes que el original de algunas obras. Entre ellas está la versión española que hizo su amigo Néstor Ibarra del «Cemetière marin» de Paul Valéry y la versión alemana de Stefan George de las Fleurs du mal de Baudelaire. El maestro argentino se detiene de manera especial en el caso de San Juan de la Cruz, a quien llama "the greatest of Spanish poets" (BORGES, 2000: 60), y hace claro que prefiere la versión inglesa de Roy Campbell del verso "Estando ya mi casa sosegada": "When all the house was hushed". "Here we have the word 'all', which gives a sense of space, of expanse, to the line. And then the gentle Word 'hushed'. 'Hushed' seems to give us somehow the very music of silence" (ibid.). Kristal también recuerda la predilección de Borges por la versión inglesa de Chaucer de la frase latina ars longa, vita brevis, pues le añadía una musicalidad melancólica: "the lyf so short, the craft so long to learn" (KRISTAL, 2002: 26). Ya sabemos, de otra parte, lo mucho que Borges reflexionó sobre «Los traductores de las Mil y una noches» -Lane, Mardrus, Galland, Burton-. Incluso llega a preguntarse, algo lúdicamente, cómo hubiera sido si a Kafka se le hubiese ocurrido traducir la obra; es decir, si hubiese organizado los juegos literarios de Scheherezade según la "deformación alemana" (KRISTAL, 2002: 30).

Observa Kristal que para Borges no hay texto que resulte "intraducible" (BORGES, 1999: 321), porque la falta de correspondencia exacta entre una lengua y otra da pie a posibilidades literarias insospechadas. "Borges would agree 
with George Steiner's contention that a translation can tap into potentialities unrealized in the original" (KRISTAL, 2002: 7). Y esto nos lleva a proponer que la "derrota" de la busca binaria de Averroes / Borges puede concluir en una inesperada victoria literaria, tan cíclica y tan reiterada como las buscas del relato. Acaso Averroes fracasa como filósofo al traducir "equivocadamente" a Aristóteles, pero justamente gracias a ello "crea" una nueva obra literaria, esta vez ficcional, en la que leemos con asombro que la Poética griega podría tener correspondencias secretas con el Corán y la mohalaca. Al traer a la vida a un Averroes hispanizado, en diálogo intertextual con los arabistas que habrían de ocuparse de su obra siglos después -Renan, Lane, Asín- Borges repite el curioso hallazgo artístico del cadí de Córdoba. Con sus adarmes culturales, modestos pero modernos, urde una obra literaria en la que el cadí de Al-Andalus adquiere novedosos rasgos occidentales, ya que está incrustado en un relato del siglo XX que el remoto Ibn Rušd histórico hubiera sido incapaz de entender.

Hemos estado hablando pues de dos buscadores, de dos buscas y de dos derrotas inherentes al cuerpo textual del relato. Habíamos advenido también a la sorpresa de que el solo hecho de volver a modular cíclicamente el circuito de fracasos implicaba una secreta victoria sobre el tiempo. Pero ahora advertimos que no se trata de una sola victoria: el relato nos asoma también a dos traductores, a dos traducciones y a dos otros triunfos, ya que tanto Averroes como Borges han creado nuevas obras literarias justamente a partir de sus errores de traslación. Además, también el rotundo fracaso de la traducción imposible de la Trascendencia termina por ser un logro artístico: el relato de Borges, que apunta con silenciosa complicidad a los hermosos textos místicos de Algacel, tan famosos en el Islam, constituye una extraordinaria pieza literaria. Todas las derrotas culminan en última instancia en el inesperado triunfo de la literatura.

A los lectores también nos es dado compartir vicariamente esta victoria letrada, ya que la habremos de invocar y de replantear cíclicamente en nuestros propios comentarios al relato. El regressus ad infinitum que nos ha planteado Borges en este encendido homenaje a las Mil y una noches que es «La busca de Averroes» termina, ya lo sabemos, por geminarlo con Ibn Rušd y con Gazzalī-pero también con nosotros-. Es una esfera cíclica tan vertiginosa como fraterna.

\section{BIBLIOGRAFÍA}

Asín PALAcios, Miguel (1934-1943), La espiritualidad de Algacel y su sentido cristiano, Madrid.

BAteson, Mary Catherine (1970), Structural Continuity in Poetry. A Linguistic study of five Pre-Islamic Arabic Odes, The Hague/Paris, Mouton \& Co.

Borges, Jorge Luis (1989), Obras completas, 4 vols., Buenos Aires, Emecé Editores, (Abrevio: OC.).

BORGES, Jorge Luis (1999), «El oficio de traducir», en Borges en Sur 1931-1980, Buenos Aires, Emecé. 
BORGES, Jorge Luis (2000), This Craft of Verse, ed. de Calin-Andrei-Mihailescu, Cambridge, Harvard, University Press.

Cabanelas, Darío (1986), Ibn Sìda de Murcia: el mayor lexicógrafo de Al-Andalus, Murcia, Editora Regional.

Corriente, Federico y Monferrer Sala, Juan Pedro, eds. (2005), Las diez Mu'allaqât. Poesía y panorama de Arabia en vísperas del Islam (Traducción literal y completa de los diez poemas originales, anotada y comentada), Madrid, Hiperión.

Cruz Hernández, Miguel (1986), Abu-l-Walid Ibn Rushd, Averroes. Vida, obra, pensamiento, influencia, Córdoba, Apéndice I.

Cruz Hernández, Miguel (1996), Historia del pensamiento en el mundo islámico, 3 vols., Madrid, Alianza / Universidad Textos.

DodDs, Jerrilyn D. y Menocal, María Rosa (2007), The Arts of Intimacy. Christians, Jews and Muslims in the Making of Castilian Culture, New Haven y London, Yale University Press.

ECHAVARRíA, Arturo (2006a), Lengua y literature de Borges, Madrid/Frankfurt, Iberoamericana/Vervuert.

ECHAVARRÍA, Arturo (2006b), El arte de la jardinería china en Borges y otros ensayos, Madrid, Iberoamericana/Vervuert.

ELIOT, Thomas Stearns (1941), «Tradition and the Individual Talent», en Points of View, New York, Faber \& Faber.

FISHBURN, Evelyn (2004a), «Traces of The Thousand and One Nights in Borges», en Variaciones Borges 17, Journal of Philosophy, Semiotics and Literature edited by the Borges Center for Studies and Documentation, Denmark, University of Aarhus, pp. 144-158.

FISHBURN, Evelyn (2004b), «Readings and Re-readings of Night 60», en Variaciones Borges 18, Journal of Philosophy, Semiotics and Literature edited by the Borges Center for Studies and Documentation, Denmark, University of Aarhus, pp. 35-42.

Fishburn, Evelyn y Hugues, Psiche (2004), A Dictionary of Borges, prefacio de Mario Vargas Llosa y Anthony Burges, London, Duckworth.

HuART, Clément (1947), Literatura árabe, Buenos Aires, Editorial Arábigo-argentina "El Nilo".

Hulme, Peter (1979), «The Face in the Mirror: Borges's 'La busca de Averroes'», Forum for Modern Language Studies, XV, pp. 292-297.

KING, James R. (1977), «Averroes' Search: the 'Moment' as Labyrinth in the Fiction of Jorge Luis Borges», Research Studies, XLV, pp. 134-146.

KRISTAL, Efraín (2002), Invisible Work. Borges and Translation, Nashville, Vanderbilt University Press.

LóPEZ-BARALT, Luce (1996), «Lo que había del otro lado del zahir de Jorge Luis Borges», en Conjurados. Anuario Borgeano, Centro de Estudios Jorge Luis Borges (Alcalá de Henares)/Franco Maria Ricci, vol. I, pp. 90-109. 
LÓPEZ-BARALT, Luce (1999), «Borges o la mística del silencio», en Jorge Luis Borges. Pensamiento y saber en el siglo XX, Alfonso y Fernando de Toro (eds.), Frankfurt, Vervuert/Iberoamericana, pp. 29-70. Traducida como «Borges or the Mystique of Silence: What Was on the Other Side of the Zahir», en J.L. Borges. Thought and Knowledge in the XXth Century, Alfonso y Fernando de TORO (eds.), Frankfurt, Vervuert/Iberoamericana, pp. 29-70.

LÓPEZ-BARALT, Luce (1999a), «Borges y William James: el problema de la expresión del fenómeno místico», en El siglo de Borges, vol. I, Retrospectiva-Presente-Futuro, Alfonso y Fernando de Toro (eds.), Frankfurt/Madrid, Vervuert/Iberoamericana, pp. 223-246.

LÓPEZ-BARALT, Luce (1999b), «Los paseos de Borges por Constitución: la clave secreta de un emblema místico privado», en El siglo de Borges, vol. II, Literatura-Ciencia-Filosofía, Alfonso de TORO y Susanna REGAZZONI (eds.), Frankfurt, Madrid, Vervuert/Iberoamericana, pp. 151-170.

LÓPEZ-BARALT, Luce (1999), «El cálamo supremo (al-qalām al-a'lā) de Cide Hamete Benengeli», Mélanges María Soledad Carrasco, Zaghouan, Tunisia, FTERSI.

LÓPEZ-BARALT, Luce (2000), «The Supreme Pen (al-qalām al-a'lā) of Cide Hamete Benengeli in Don Quixote», Journal of Medieval and Early Modern Studies, 30:3, 2000, pp. 505-518.

LÓPEZ-BARALT, Luce (2004), El viaje maravilloso de Buluqiya a los confines del universo, edición, traducción, estudio introductorio y notas de L. López-Baralt, Madrid, Trotta.

LÓPEZ-BARALT, Luce (2007), «El coloquio de los pájaros: Borges y 'Attar de Nishapur», en El laberinto de los libros: Jorge Luis Borges frente al canon literario, Alfonso de Toro (ed.), Zürich-New York, Georg Olms Verlag, Hildesheim, pp. 175-183. (Versión abreviada en: Humanistas del año. Dres. Arturo Echavarría y Luce López-Baralt, Fundación Puertorriqueña de las Humanidades, 2003, pp. 25-35.)

LÓPEZ-BARALT, Luce (2011), «Los laberintos islámicos de Jorge Luis Borges» (en prensa, Instituto Van Der Leer, Jerusalén).

LÓPEZ-BARALT, Luce (2011), «Islamic Themes in Jorge Luis Borges» (en prensa, Borges' Companion, Cambridge University Press).

Moliner, María (1994), Diccionario del uso del español (2 vols.), Madrid, Gredos. Renan, Ernest (1852), Averroes et l'averroïsme. Essai Historique, París.

Robinson, Cynthia (2002), In Praise of Song. The Making of Courtly Culture in AlAndalus and Provence, 1005-1134 A.D., Leiden, Brill.

TORniELli, Pablo (2001), «Algunos motivos árabes e islámicos en la obra de Borges», Borges Studies On Line, www.almendron.com/cuaderno/varios / borges61.pdf.

ZuhAYr b. Abī Sulmà (1981), Mu'allaqāt , Beirut, Dār Șa'b. 


\title{
RESUMEN
}

Análisis del relato "La busca de Averroes", de Jorge Luis Borges, a partir de la doble búsqueda que plantea la narración: de Averroes por parte de Borges y de Aristóteles por parte de Averroes. A través del análisis de los diferentes elementos del relato, éste se filia con varios de los elementos más presentes en la narrativa y pensamientos borgianos: la insuficiencia del lenguaje para expresar la trascendencia, las paradojas literarias de la traducción, la fricción entre la articulación intelectual y el sentimiento místico o los sutiles juegos cromáticos. Compleja y delicada en su construcción, la narración se muestra como una vindicación del triunfo de la literatura al final de una sucesión de derrotas motivadas esencialmente por la incapacidad de observación de lo real.

Palabras clave: Borges, Averroes, Algacel, mística, Falsafa, traducción.

\begin{abstract}
Analysis of the tale "Averroes' search", by Jorge Luis Borges, from the double search proposed in the narrative: of Averroes by Borges and of Aristotle by Averroes. Through the analysis of the different elements of the tale, this is related to the typical elements of Borges' narrative and thought: the limitation of language to express the transcendental, the literary paradoxes of translations, the friction between the intellectual articulation and the mystical experience, or the subtle chromatic symbolism. Complex and delicate in its construction, the tale is presented as a vindication of the triumph of literature after a sequence of defeats due, in essence, to the impossibility of observing reality.
\end{abstract}

Key words: Borges, Averroes, Algazel, mysticism, Falsafa, translation. 